\title{
Perencanaan Sistem Penyaluran dan Pengolahan Air Limbah Domestik Kecamatan Semarang Barat Kota Semarang
}

\author{
Aulia Rahmanissa dan Agus Slamet \\ Departemen Teknik Lingkungan, Fakultas Teknik Sipil dan Perencanaan, Institut Teknologi Sepuluh Nopember \\ (ITS) \\ e-mail: suga@enviro.its.ac.id
}

\begin{abstract}
Abstrak-Kecamatan Semarang Barat yang ditetapkan sebagai kawasan permukiman, perdagangan, dan jasa, belum memiliki sistem pengolahan air limbah. Kecamatan Semarang Barat merupakan kecamatan dengan kepadatan tinggi sehingga menurut Perda Kota Semarang No. 14 tahun 2011 membutuhkan sistem pengolahan secara komunal. Perencanaan sistem pengolahan air limbah terdiri dari sistem penyaluran (SPAL) dan instalasi pengolahan (IPAL) beserta rencana investasinya. Perencanaan diawali dengan membagi area pelayanan menjadi 5 cluster. Pengumpulan data primer meliputi survei lokasi dan kualitas influen air limbah. Data sekunder yang dibutuhkan adalah jumlah penduduk, rekening PDAM pelanggan, peta wilayah, baku mutu air limbah domestik, dan HSPK Kota Semarang tahun 2016. Perencanaan sistem penyaluran air limbah ini menggunakan sistem shallow sewer. Unit IPAL menggunakan kombinasi anaerobic baffled reactor -anaerobic filter. Sistem penyaluran menggunakan konsep shallow sewer. Jenis pipa yang digunakan adalah PVC dengan diameter $100 \mathrm{~mm}-250 \mathrm{~mm}$. Kualitas influen yang diolah adalah BOD $162 \mathrm{mg} / \mathrm{L}$, COD $268 \mathrm{mg} / \mathrm{L}$, dan TSS 210 $\mathrm{mg} / \mathrm{L}$. IPAL yang direncanakan adalah ABR-AF yang terbagi menjadi beberapa unit dan disusun secara paralel. Cluster 1 terdiri dari 3 unit dengan luas 106,42 $\mathrm{m}^{2}$. IPAL cluster 2 terdiri dari 3 unit dengan luas $122,47 \mathrm{~m}^{2}$. Cluster 3 terdiri dari 1 unit dengan luas $28,5 \mathrm{~m}^{2}$. IPAL cluster 4 terdiri dari 3 unit dengan luas 244,2 $\mathrm{m}^{2}$. Cluster 5 terdiri dari 3 unit dengan luas 151,62 $\mathrm{m}^{2}$. Rencana investasi per KK antara Rp 2.500.000,00 hingga Rp 5.000.000,00 dan biaya retribusi $R p$ 3.000- 5.000 /bulan.
\end{abstract}

Kata Kunci-ABR, AF, Domestik, SPAL, Semarang

\section{PENDAHULUAN}

$\mathrm{K}$ OTA Semarang sebagai salah satu kota besar di Indonesia sekaligus ibukota dari Provinsi Jawa Tengah tak luput dari permasalahan air limbah. Penanganan air limbah greywater di Kota Semarang sebanyak 94,06\% dibuang ke saluran drainase dan 5,94\% diresapkan ke dalam tanah. Blackwater, atau air limbah dari toilet, langsung dialirkan menuju septik tank atau tangki septik, sedangkan air limpasan dari tangki septik diresapkan ke tanah atau dibuang kesaluran umum [1].

Kecamatan Semarang Barat sebagai salah satu kawasan yang peruntukannya untuk permukiman, perdagangan, dan jasa, termasuk dalam daerah dengan kepadatan tinggi. Studi kasus diambil dari 5 kelurahan di kecamatan Semarang Barat, yaitu kelurahan Karangayu, Krobokan, Salamanmloyo, Cabean, dan Bojongsalaman. Daerah permukiman di 5 kelurahan tersebut masih membuang air limbahnya ke saluran drainase yang kemudian disalurkan ke sungai atau diresapkan di tanah.

Greywater yang dibuang langsung ke saluran drainase tanpa pengolahan terlebih dahulu dapat menyebabkan penipisan oksigen, peningkatan kekeruhan, eutrofikasi, serta kontaminasi mikroba dan bahan kimia terhadap badan air
[2]. Tangki septik berkontribusi sebagai sumber pencemar melalui kontaminasi langsung dan tidak langsung. Kontaminasi langsung seperti bakteri pathogen, nutrient, zat organik. Sedangkan kontaminasi tidak langsung dari masuknya air yang dapat meningkatkan penyebaran kontaminan dan atau kelangsungan mikroba [3]. Sehingga perlu adanya pengolahan terhadap greywater dan efluen dari tangki septik untuk mengurangi pencemaran terhadap lingkungan.

Pada dokumen Rencana Pembangunan Jangka Menengah Nasional (RPJMN) tahun 2015-2019 telah disebutkan mengenai target 100:0:100. Target 100:0:100 meliputi 100\% pelayanan air minum, $0 \%$ kawasan permukiman kumur, dan $100 \%$ sanitasi yang layak. Sanitasi yang dimaksud mencakup air limbah, drainase dan persampahan. Untuk penanganan air limbah, sasaran yang direncanakan adalah penambahan infrastruktur, air limbah sistem terpusat, pengolahan air limbah komunal, dan peningkatan pengelolaan lumpur tinja melalui pembangunan IPLT di berbagai kota/kabupaten di Indonesia.

Peraturan Daerah Kota Semarang Nomor 14 Tahun 2011 tentang Rencana Tata Ruang Wilayah tahun 2011-2031, menyebutkan rencana sistem pembangunan ipal komunal diarahkan untuk semua kecamatan dengan kepadatan tinggi, salah satunya adalah Kecamatan Semarang Barat. Oleh karena itu, perlu adanya perencanaan sistem pengolahan air limbah komunal di kecamatan tersebut.

Teknologi pengolahan limbah yang paling banyak digunakan di sistem pengolahan limbah skala kawasan di Indonesia adalah Anaerobic Baffled Reactor (ABR). Teknologi ini dipilih karena memiliki beberapa kelebihan seperti biaya operasional yang rendah, efisiensi pengolahan tinggi, tidak memakan banyak lahan karena dapat dibangun di bawah tanah [4]. Salah satu kelemahan dari ABR adalah penyisihan suspended solid yang rendah dan dapat terbawanya suspended solid ke outlet [5]. Media filter diletakkan pada kompartemen akhir untuk menahan suspended solid agar tidak ikut terbawa keluar outlet. Unit pengolahan yang direncanakan adalah anaerobic baffled reactor dengan kombinasi anaerobic filter [6].

\section{GAMBARAN UMUM WILAYAH}

Kecamatan Semarang Barat terdiri dari 16 kelurahan. Wilayah studi yang dipilih adalah 5 kelurahan, yaitu Kelurahan Karangayu, Krobokan, Salamanmloyo, Cabean, dan Bojong Salaman. Kelima kelurahan tersebut dipilih karena merupakan kelurahan dengan permukiman padat. Pada wilayah tersebut akan dilayani dalam perencanaan SPAL dan juga akan disediakan unit bangunan IPAL Komunal untuk kawasan permukimannya. Lokasi daerah perencanaan dapat dilihat pada Gambar 1. 


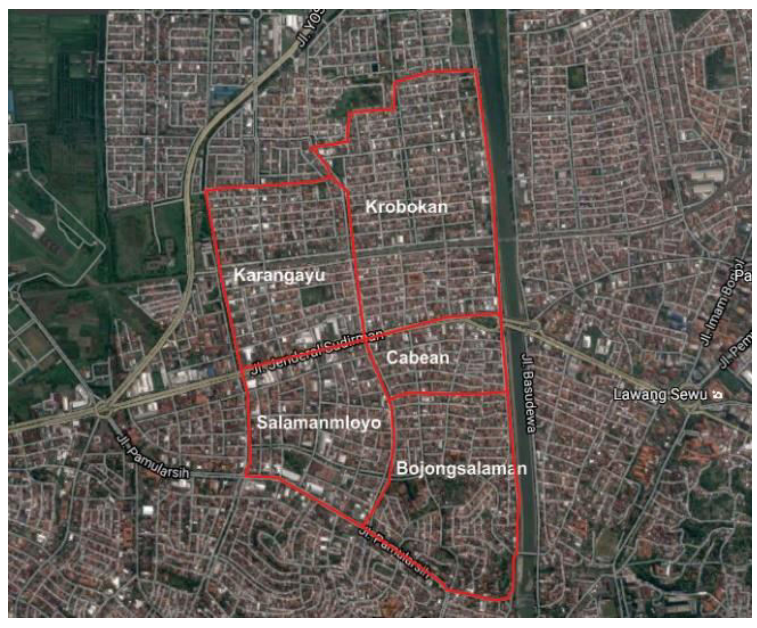

Gambar 1. Peta Daerah Perencanaan.

Sumber: Citra satelit Google Earth, 2017

Sebagian besar wilayah perencanaan merupakan dataran dengan elevasi datar. Untuk kelurahan Salamanmloyo dan Bojongsalaman, memiliki area yang elevasinya lebih tinggi dari area lainnya. Jumlah penduduk yang tinggal di Kelurahan Karangayu, Krobokan, Salamanmloyo, Cabean, dan Bojongsalaman berjumlah 40.048 jiwa. Total luas daerah adalah $2,79 \mathrm{~km}^{2}$.

\section{METODE PERENCANAAN}

\section{A. Pengumpulan Data}

Pengumpulan data dibutuhkan dalam perencanaan ini. Data yang dibutuhkan dibagi menjadi dua, yaitu data primer dan data sekunder. Data- data tersebut antara lain:

a. Data Primer

- Survei Lokasi

Survei lokasi dibutuhkan untuk melihat langsung kondisi yang ada di lapangan, berupa rencana lokasi penempatan IPAL, luas lahan dan kondisi jalan

- Kualitas Influen Air Limbah

Kualitas influen air limbah didapatkan dengan mengambil sampel dengan cara random sampling pada saluran air buangan permukiman, Sampel kemudian diuji sesuai dengan parameter BOD, COD, TSS, pH, minyak dan lemak. Parameter ini sesuai dengan parameter baku mutu air limbah Peraturan Menteri Lingkungan Hidup No. 68 tahun 2016

b. Data Sekunder

- Rekening air pelanggan PDAM

- Jumlah penduduk

- Peta RTRW

- Baku mutu air limbah menurut Peraturan Menteri Lingkungan Hidup No. 68 tahun 2016 tentang baku mutu air limbah domestik

- Harga satuan pokok (HSPK) Kota Semarang tahun 2016

\section{B. Analisis dan Pembahasan}

Pada bagian ini dibahas mengenai dua aspek yaitu, aspek teknis dan finansial. Pembahasan aspek teknis meliputi pengolahan data primer dan sekunder, perencanaan sistem penyaluran air limbah dan perencanaan instalasi pengolahan air limbah yang digunakan beserta penyusunan gambar jalur SPAL, denah, potongan, detail dan profil hidrolis. Untuk aspek biaya meliputi perhitungan BOQ dan RAB yang disesuaikan dengan harga satuan pokok (HSPK) di Kota Semarang tahun 2016.

\section{HASIL DAN PEMBAHASAN}

\section{A. Penentuan Debit Perencanaan}

Debit air bersih diketahui dari rata-rata pemakaian air PDAM selama 3 bulan terakhir (Desember 2016 - Februari 2017). Pemakaian air bersih per orang per hari adalah 180,6 L/orang/hari. Debit air limbah ditetapkan dari $80 \%$ pemakaian air bersih, sehingga didapatkan debit air limbah adalah 144,5 L/orang/hari.

\section{B. Penentuan Cluster}

Daerah perencanaan memiliki total penduduk sebesar 40.408 orang. karena banyaknya jumlah penduduk yang terlayani, maka dibuat sistem cluster untuk mencegah dimensi ipal yang besar, mengurangi kebutuhan lahan pada satu tempat serta mengurangi biaya pemompaan karena penanaman pipa yang terlalu dalam. Wilayah terbagi menjadi 5 cluster yang berbeda. Pembagian cluster dapat dilihat pada Tabel 1.

Tabel 1.

Pembagian Cluster

\begin{tabular}{lll}
\hline \hline Cluster & Kelurahan & Jumlah Penduduk (jiwa) \\
Cluster 1 & Salaman Mloyo & 3624 \\
Cluster 2 & Karangayu & 3664 \\
Cluster 3 & Cabean, Bojongsalaman & 12072 \\
Cluster 4 & Krobokan & 15604 \\
Cluster 5 & Karangayu & 5332 \\
\hline \hline
\end{tabular}

Peta pembagian cluster dapat dilihat pada Gambar 1.

Cluster 1, 2, 4, dan 5 memanfaatkan lahan kosong atau fasilitas umum untuk penempatan instalasi pengolahan air limbah (IPAL) akan. Penempatan IPAL cluster 3 akan berada di bawah jalan permukiman karena keterbatasan lahan. Sehingga untuk cluster 3 berupa desain IPAL yang tipikal untuk kapasitas pelayanan tertentu.

\section{Perencanaan Sistem Penyaluran Air Limbah (SPAL)}

Sistem penyaluran air limbah (SPAL) menggunakan sistem shallow sewer. Sistem tersebut cocok diterapkan untuk permukiman yang belum teratur dan memiliki kepadatan tinggi. Sistem penyaluran terbagi menjadi saluran tersier, sekunder dan primer. Jaluran dan lokasi IPAL per cluster dapat dilihat pada Gambar 3 hingga Gambar 7.

Dalam merencanakan SPAL slope penting dalam perhitungan dimensi. Daerah perencanaan sebagian besar adaalah area dengan elevasi datar, sehingga perlu ditentukan slope rencana. Slope minimum ditentukan sebesar 0,003. Diameter pipa yang digunakan untuk shallow sewer adalah $100 \mathrm{~mm}-250 \mathrm{~mm}$. Jenis pipa adalah PVC tipe AW.

\section{Perencanaan Instalasi Pengolahan Air Limbah (IPAL)}

Kualitas influen berrdasarkan hasil sampling untuk perencanaan ini dapat dilihat pada Tabel 2.

Tabel 2.

Karakteristik Air Limbah

\begin{tabular}{lccc}
\hline \hline Parameter & Satuan & Hasil Analisis* & Baku Mutu** \\
\hline BOD & mg/L & 162 & 30 \\
COD & mg/L & 268 & 100 \\
TSS & mg/L & 210 & 30 \\
Minyak dan & mg/L & 20 & 5 \\
Lemak & & & \\
Amoniak & mg/L & 48,57 & 10 \\
pH & & 6,95 & $6-9$ \\
Total Coliform & MPN/100ml & $22 \times 10^{8}$ & 3000 \\
\hline
\end{tabular}

*Laboratorium Manajemen Kualitas Lingkungan ITS, 2017 
**Peraturan Menteri Lingkungan Hidup dan Kehutanan No. 68 Tahun 2016

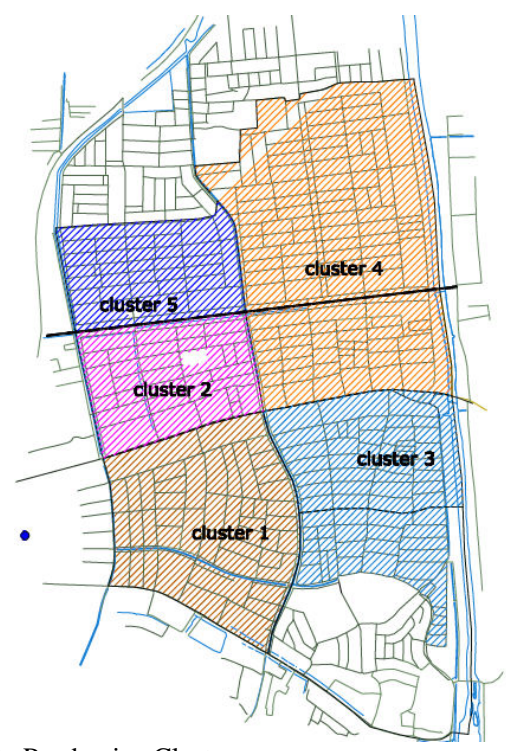

Gambar 2. Peta Pembagian Cluster.

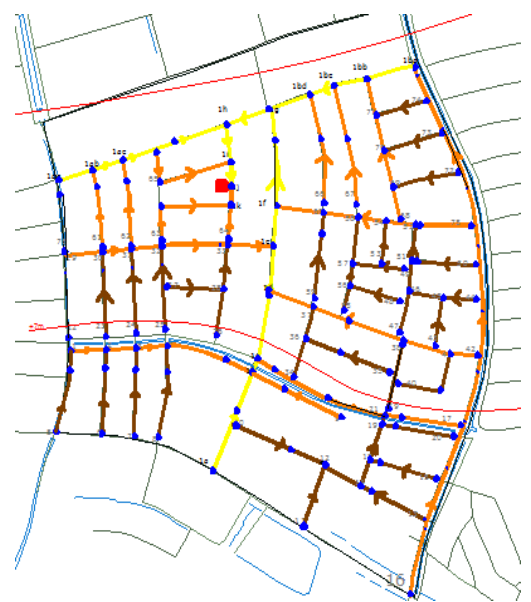

Gambar 3. Jalur SPAL dan lokasi IPAL Cluster 1.

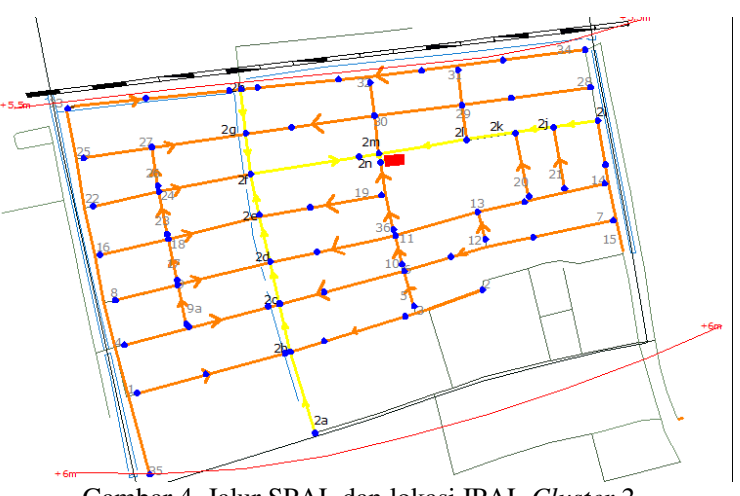

Gambar 4. Jalur SPAL dan lokasi IPAL Cluster 2.

Unit IPAL yang direncanakan merupakan kombinasi anaerobic baffled reactor dan anaerobic filter (ABR-AF). Kompartemen anaerobic filter diletakkan setelah kompartemen ABR. Media filter yang digunakan adalah media sarang tawon. Debit perencanaan besar sehingga IPAL terbagi menjadi beberapa unit secara paralel untuk mendapatkan efisiensi yang optimum. Semua cluster memanfaatkan lahan kosong atau fasilitas umum yang ada, kecuali cluster 3. Cluster 3 memanfaatkan jalan permukiman, sehingga unit IPAL direncanakan tipikal.

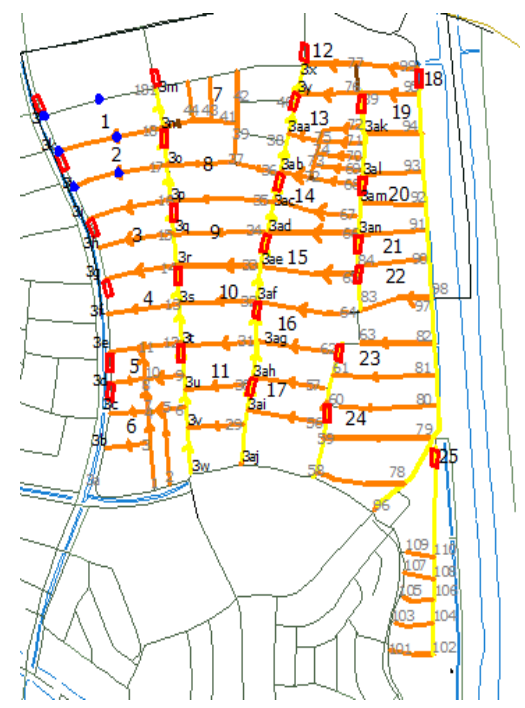

Gambar 5. Jalur SPAL dan lokasi IPAL Cluster 3.

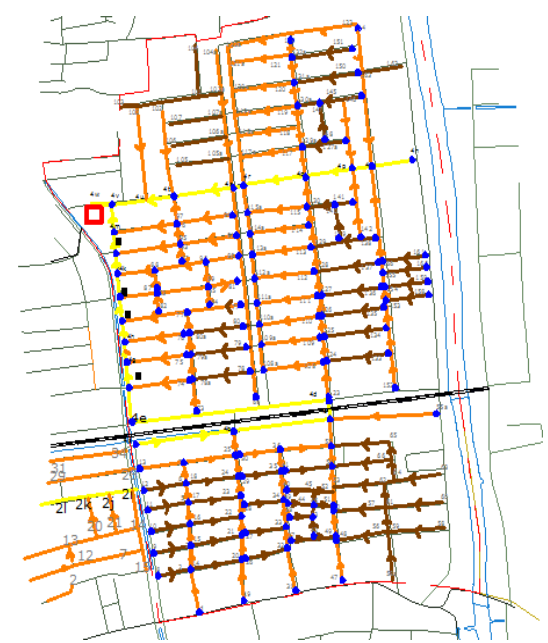

Gambar 6. Jalur SPAL dan lokasi IPAL Cluster 4.

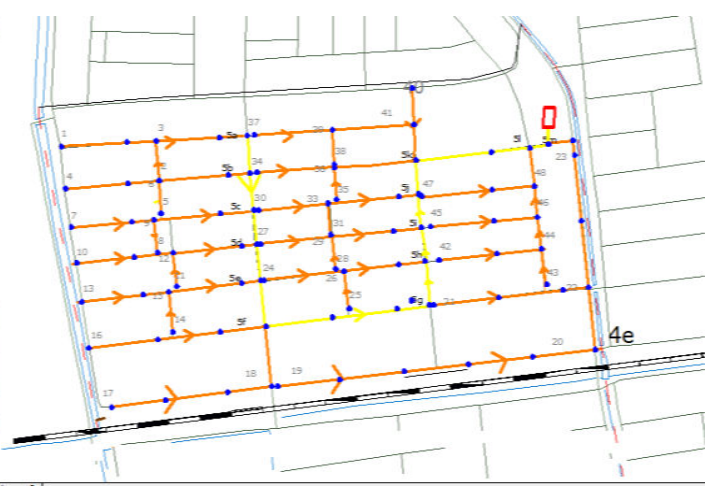

Gambar 7. Jalur SPAL dan lokasi IPAL Cluster 5.

Diagram alir unit IPAL untuk semua cluster ditetapkan sama, sebagaimana dijelaskan pada Gambar 8 .

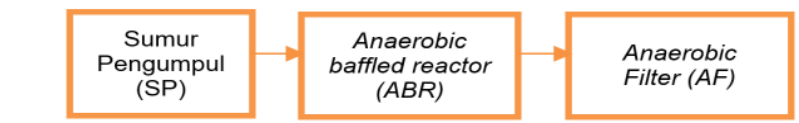

Gambar 8. Diagram pengolahan.

Perhitungan dimensi mengacu pada kriteria desain sebagai berikut [7]: 
$\underline{\text { Kriteria desain ABR }}$

\begin{tabular}{lll}
\hline Removal COD & $=65 \%-90 \%$ \\
Removal BOD & $=70 \%-95 \%$ \\
Hydraulic Retention Time (HRT) & $=6-24 \mathrm{jam}$ \\
Kecepatan aliran (Vup) [8] & $=<1,0 \mathrm{~m} / \mathrm{jam}$ \\
Jumlah kompartemen & $=3-6$ \\
Kriteria desain AF & \\
Luas permukaan media & $=90-300 \mathrm{~m}^{2} / \mathrm{m}^{3}$ \\
Organic loading & $=4-5 \mathrm{~kg} \mathrm{COD} / \mathrm{m}^{3}$. hari \\
Hydraulic retention time & $=1,5-2 \mathrm{hari}$
\end{tabular}

Hasil perhitungan dimensi unit IPAL adalah sebagai berikut Cluster 1

Cluster 1 melayani 3624 jiwa (908 KK). Debit air limbah domestik sebesar 7,4 L/detik. IPAL terbagi menjadi 3 unit ABR-AF sehingga debit pengolahan untuk 1 unit adalah 2,5 L/detik.

Hasil perencanaan unit IPAL terdiri dari bak pengendap, anaerobic baffled reactor ddengan 4 kompartemen dan 1 kompartemen anaerobic filter. Dimensi total IPAL yang dibutuhkan adalah 15,65 m x 6,8 m x 4,2 m dengan kualitas efluen COD dan BOD masing-masing 21,5 mg/L dan 8,95 $\mathrm{mg} / \mathrm{L}$.

Cluster 2

Cluster 2 melayani 3664 jiwa (916 KK). Debit air limbah domestik sebesar 7,5 L/detik. IPAL terbagi menjadi 3 unit ABR-AF sehingga debit pengolahan untuk 1 unit adalah 2,5 L/detik.

Hasil perencanaan unit IPAL terdiri dari bak pengendap, anaerobic baffled reactor dengan 4 kompartemen dan 1 kompartemen anaerobic filter. Dimensi total IPAL yang dibutuhkan adalah $16,55 \mathrm{~m} \times 7,4 \mathrm{~m} \times 4,05 \mathrm{~m}$ dengan kualitas efluen COD dan BOD masing -masing 19,29 mg/L dan $7,98 \mathrm{mg} / \mathrm{L}$.

Cluster 3

Cluster 3 melayani 12072 jiwa. Keterbatasan lahan membuat IPAL pada cluster ini dibuat 1 unit tipikal untuk pelayanan $100-150 \mathrm{KK}$. Debit air limbah domestik untuk $150 \mathrm{KK}$ adalah $1,5 \mathrm{~L} /$ detik.

Hasil perencanaan unit IPAL terdiri dari bak pengendap, anaerobic baffled reactor dengan 5 kompartemen dan 1 kompartemen anaerobic filter. Dimensi total IPAL yang dibutuhkan adalah $15 \mathrm{~m} \times 1,9 \mathrm{~m} \times 3,6 \mathrm{~m}$ dengan kualitas efluen COD dan BOD masing -masing 19,29 mg/L dan 7,98 $\mathrm{mg} / \mathrm{L}$.

Cluster 4

Cluster 4 melayani 15604 jiwa (5147 KK). Debit yang diolah adalah 26,3 L/detik. IPAL terbagi menjadi 4 unit ABR-AF sehingga debit pengolahan untuk 1 unit adalah 6,67 L/detik.

Hasil perencanaan unit IPAL terdiri dari bak pengendap, 5 kompartemen anaerobic baffled reactor dan 1 kompartemen anaerobic filter. Dimensi total IPAL yang dibutuhkan adalah 20,35 m x $12 \mathrm{~m}$ x 3,7 m dengan kualitas efluen COD dan BOD masing -masing 19,26 mg/L dan 8,93 $\mathrm{mg} / \mathrm{L}$.

Cluster 5

Cluster 4 melayani 15604 jiwa (5147 KK). Debit yang diolah adalah $110 \mathrm{~L} /$ detik. IPAL terbagi menjadi 3 unit ABR-AF sehingga debit pengolahan untuk 1 unit adalah 6,67 L/detik.

Hasil perencanaan unit IPAL terdiri dari bak pengendap, anaerobic baffled reactor dengan 4 kompartemen dan 1 kompartemen anaerobic filter. Dimensi total IPAL yang dibutuhkan adalah $18,05 \mathrm{~m} \mathrm{x} 8,4 \mathrm{~m} \times 4,2 \mathrm{~m}$ dengan kualitas efluen COD dan BOD masing -masing 20,19 mg/L dan 7,44 $\mathrm{mg} / \mathrm{L}$.

Gambar dari salah satu unit IPAL dapat dilihat pada Gambar 9 hingga Gambar 12 di bawah ini.

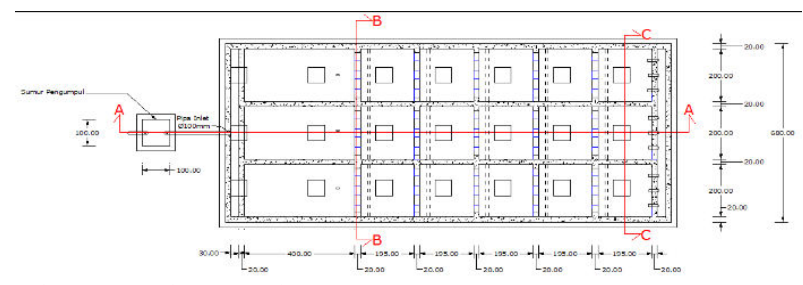

Gambar 9. Denah IPAL Cluster 1.

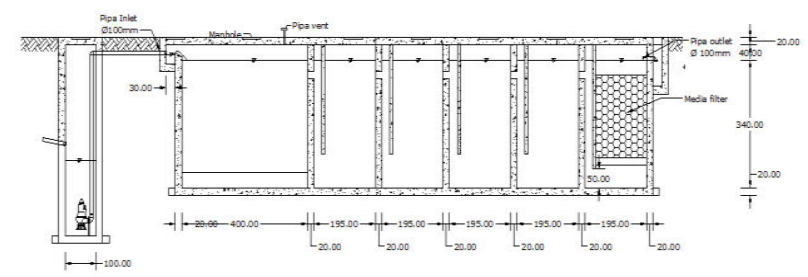

Gambar 10. Potongan A - A IPAL Cluster 1.

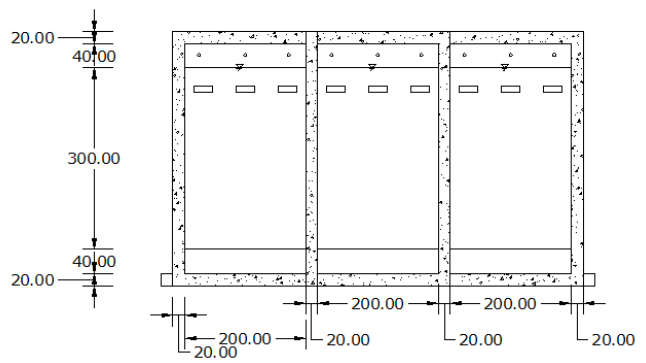

Gambar 11. Potongan B - B IPAL Cluster 1.

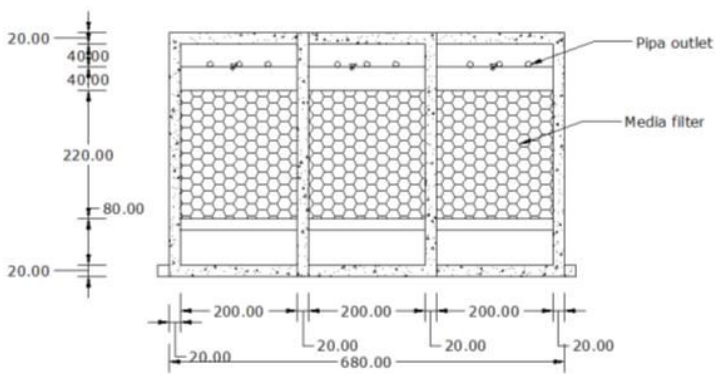

Gambar 12. Potongan C - C IPAL Cluster 1.

\section{E. Rencana Angggaran Biaya}

Rencana investasi per KK untuk konstruksi SPAL dan IPAL masing-masing cluster adalah:

1. Cluster $1=\operatorname{Rp~5.473.267,00}$

2. Cluster $2=\operatorname{Rp} 4.756 .602,00$

3. Cluster $3=\operatorname{Rp~3.983.256,00}$

4. Cluster $4=\operatorname{Rp} 2.748 .470,00$

5. Cluster $5=\operatorname{Rp} 3.110 .944,00$

Biaya retribusi yang dibayarkan per bulan untuk operasional dan pemeliharaan cluster 1, 2, dan 3 adalah Rp $5.000,00$. Biaya retribusi cluster 4 adalah $\mathrm{Rp} 3.000,00$. Biaya retribusi cluster $5 \mathrm{Rp} 4.000,00$

\section{KESIMPULAN}

Kesimpulan dari perencanaan pengolahan air limbah domestik di Kecamatan Semarang Barat, Kota Semarang ini adalah: 
1. Perencanaan pengolahan air limbah domestik terbagi menjadi 5 cluster dengan sistem penyaluran air limbah menggunakan sistem shallow sewer. Pipa yang digunakan adalah pipa PVC tipe AW dengan diameter 100 - $250 \mathrm{~mm}$.

2. Pengolahan air limbah domestik menggunakan kombinasi anaerobic baffled reactor dan anaerobic filter. Masing-masing IPAL tiap cluster meiliki dimensi sebagai berikut:

a. IPAL cluster 1 terbagi menjadi 3 unit paralel dengan masing-masing 5 kompartemen (4 baffled reactor dan 1 filter). Dimensi keseluruhan unit IPAL $15,65 \mathrm{~m}$ x 6,8 $\mathrm{m}$ x 4,2 $\mathrm{m}$

b. IPAL cluster 2 terbagi menjadi 3 unit paralel dengan masing-masing 5 kompartemen (4 baffled reactor dan 1 filter). Dimensi keseluruhan unit IPAL $16,55 \mathrm{~m} \times$ 7,4 $\mathrm{m}$ x 4,05 m

c. IPAL cluster 3 merupakan desain tipikal dengan 5 kompartemen baffled reactor dan 1 filter. Dimensi keseluruhan unit IPAL $15 \mathrm{~m}$ x 1,9 m x 3,6 m

d. IPAL cluster 4 terbagi menjadi 4 unit dengan masing-masing 5 kompartemen ( 5 baffled reactor dan 1 filter). Dimensi keseluruhan unit IPAL 20,35 $\mathrm{m} \times 12 \mathrm{~m} \times 3,7 \mathrm{~m}$.

e. IPAL cluster 5 terbagi menjadi 4 unit dengan masing-masing 5 kompartemen (4 baffled reactor dan 1 filter). Dimensi keseluruhan unit $20,35 \mathrm{~m} \mathrm{x}$ $12 \mathrm{~m} \times 3,7 \mathrm{~m}$.

3. Total rencana anggaran biaya sistem penyaluran dan pengolahan untuk masing-masing cluster adalah sebagai berikut:
- Cluster $1=$ Rp 5.473.267,00

- Cluster $2=\operatorname{Rp} 4.756 .602,00$

- Cluster $3=\operatorname{Rp} 2.140 .767,00$

- Cluster $4=$ Rp 2.748.470,00

- Cluster $5=$ Rp 3.110.944,00

4. Biaya retribusi yang dibayarkan per bulan untuk operasional dan pemeliharaan untuk 5 cluster antara Rp 3.000,00 - Rp 5.000,00.

\section{DAFTAR PUSTAKA}

[1] Syafrudin, "Ringkasan Disertasi Pengolahan Air Limbah Domestik Tipe Greywater Menggunakan Reaktor Upflow Anaerobic Sludge Blanket (UASB)," Univesitas Diponegoro, 2014.

[2] E. Tilley and S. Peters, "Sanitation Systems and Technologies," 2008

[3] W. G. Reay, "Septic Tanks Impacts on Ground Water Quality and Nearshore Sediment Nutrien Flux," Groundwater, vol. 42, no. 7, pp. 1079 - 1089, 2004

[4] WSP (Water and Sanitation Programs), "Review of CommunityManaged Decentralized Wastewater Treatment Systems in Indonesia," Washington, 2013

[5] E. Tilley, L. Ulrich, C. Lüthi, P. Reymond, and C. Zurbrügg, Compendium of Sanitation Systems and Technologies 2 nd revised edition. Dübendorf: EAWAG.

[6] E. Purwanto, "Studi Anaerobic Baffled reactor (ABR) unttuk megolah Air Limbah Domestik dari Rumah Susun," Institut Teknologi Sepuluh Nopember, 2008.

[7] L. Sasse, DEWATS. Decentralized Wastewater Treatment in Developing Countries. Bremen: Borda, 2009.

[8] G. Tchobanoglous, F. L. Burton, and H. D. Stensel, Wastewater Engineering: Treatment and Resource Recovery, 4th ed. New York: Mc Graw Hill, 2003. 